\title{
Occult HBV infection status and its impact on surgical outcomes in patients with curative resection for HCV-associated hepatocellular carcinoma
}

\author{
Koutaro Yamaji ${ }^{1,2}$, Keita Kai ${ }^{3}$, Sho Komukai ${ }^{4}$, Hiroki Koga ${ }^{1}$, Takao Ide ${ }^{1}$, Atsushi Kawaguchi ${ }^{5}$, \\ Hirokazu Noshiro ${ }^{1}$, Shinichi Aishima ${ }^{2,3}$ \\ ${ }^{1}$ Department of Surgery, ${ }^{2}$ Department of Pathology \& Microbiology, Saga University Faculty of Medicine, Saga 849-8501, Japan; ${ }^{3}$ Department of \\ Pathology, ${ }^{4}$ Clinical Research Center, Saga University Hospital, Saga 849-8501, Japan; ${ }^{5}$ Center for Comprehensive Community Medicine, Saga \\ University Faculty of Medicine, Saga 849-8501, Japan \\ Contributions: (I) Conception and design: K Kai; (II) Administrative support: K Kai, A Kawaguchi, H Noshiro, S Aishima; (III) Provision of study \\ material or patients: K Yamaji, K Kai, H Koga, T Ide, H Noshiro; (IV) Collection and assembly of data: K Yamaji, K Kai, S Komukai, H Koga, T \\ Ide, S Aishima; (V) Data analysis and interpretation: K Yamaji, K Kai, S Komukai, A Kawaguchi; (VI) Manuscript writing: All authors; (VII) Final \\ approval of manuscript: All authors. \\ Correspondence to: Dr. Keita Kai. Department of Pathology, Saga University Hospital, Nabeshima 5-1-1, Saga City, Saga 849-8501, Japan. \\ Email: kaikeit@cc.saga-u.ac.jp.
}

Background: We sought to clarify the prevalence of occult hepatitis B virus (HBV) infection (OBI) and to determine whether OBI affects the surgical outcomes in curatively resected Japanese patients with hepatitis C virus (HCV)-related hepatocellular carcinoma (HCC).

Methods: A total of 257 patients with HCV-related HCC who underwent curative surgical resection were enrolled. All enrolled patients were serologically negative for HBV surface antigen and positive for HCV antibody. DNA was extracted from formalin-fixed paraffin-embedded liver tissue. OBI was determined by the HBV-DNA amplification of at least two different sets of primers by TaqMan real-time polymerase chain reaction. Surgical outcomes were evaluated according to overall survival (OS), disease-specific survival (DSS), and disease-free survival (DFS).

Results: OBI was identified in 15 of the 257 (5.8\%) cases. In the multivariate analyses, the factors significantly correlated with OS were $\mathrm{BMI}>25(\mathrm{P}=0.0416)$, portal vein invasion $(\mathrm{P}=0.0065)$, and multiple tumors $(\mathrm{P}=0.0064)$. The only factor significantly correlated with DSS was T-stage $(\mathrm{P}=0.0275)$. The factors significantly correlated with DFS were liver fibrosis $(\mathrm{P}=0.0017)$ and $\mathrm{T}$-stage $(\mathrm{P}=0.0001)$. The status of OBI did not show any significant correlation with OS, DSS or DFS, but a weak association with DSS $(\mathrm{P}=0.0603)$ was observed.

Conclusions: The prevalence of OBI was 5.8\% in 257 cases of HCV-related HCC. Although a weak association between DSS and OBI was observed, and statistical analyses were limited by small number of OBI cases, no significant correlation between OBI and surgical outcomes was detected.

Keywords: Occult hepatitis B virus infection (OBI); hepatocellular carcinoma (HCC); hepatitis C virus (HCV); surgery; prognosis

Submitted Jul 30, 2018. Accepted for publication Oct 09, 2018.

doi: $10.21037 /$ hbsn.2018.10.01

View this article at: http://dx.doi.org/10.21037/hbsn.2018.10.01 


\section{Introduction}

Hepatocellular carcinoma (HCC) is one of the most common malignant tumors, and in Japan it is the fourth leading cause of death among men and the sixth leading cause of death among women (1). Chronic hepatitis B virus (HBV) and hepatitis $\mathrm{C}$ virus (HCV) infections are major risk factors for HCC. The prevalence of $\mathrm{HBV}$ and $\mathrm{HCV}$ infections varies among geographic regions. In Japan, $\mathrm{HCV}$ infection is the most common etiology for HCC, accounting for approx. $70 \%$ of all HCC cases (2).

Occult HBV infection (OBI) is generally defined as negative $\mathrm{HBV}$ surface antigen ( $\mathrm{HBsAg}$ ) and positive or negative anti-hepatitis B core (anti-HBc) immunoglobulin G (IgG) status but HBV DNA is detectable in the serum and/or liver tissue (3), and OBI was recognized as one of the risk factors for the development of HCC (4). It has been speculated that OBI accelerates the progression of liver fibrosis in patients with chronic hepatitis $\mathrm{C}(\mathrm{CHC})$ and initiates the development of HCC in patients with $\mathrm{CHC}$ (4-13). However, several studies have reported that OBI is not associated with the disease progression of $\mathrm{CHC}$ or the development of HCC (14-18). The influence of OBI on patients with $\mathrm{CHC}$ thus remains controversial.

Although there have been several studies regarding OBI and HCC in Japan $(7,10,18,19)$, the evidence obtained in those studies is not sufficient for any conclusion regarding the relationship between OBI and HCC (such as prevalence and clinicopathological characteristics) in a Japanese population. The accumulation of further studies regarding OBI and HCC in Japanese subjects is needed. We have focused on the influence of OBI on surgical outcomes of HCC patients, because no previous Japanese OBI studies focused on this issue, although curative surgical resection is the most frequent therapeutic strategy for HCC.

The mortality rate for HCC in Saga Prefecture (located on the island of Kyushu, the southwestern-most of Japan's main islands) where our hospital is located, had been the worst in Japan for over 18 years. We thus consider that it is important to investigate the status of OBI in HCC patients in Saga Prefecture, particularly since the relationship between OBI and HCC is controversial. We previously investigated the prevalence and influence of surgical outcomes of OBI patients with neither hepatitis $\mathrm{B}$ nor hepatitis C (NBNC)-HCC treated at our hospital, and we found a $34.6 \%$ prevalence of OBI and no influence of OBI on the surgical outcomes of NBNC-HCC patients (20). As the next step in the investigation, we focused in the present study on the influence of OBI on patients with HCC based on HCV infection (C-HCC), which accounts for the majority of HCC patients in Saga Prefecture, and we determined the surgical outcomes of these patients after curative hepatic resection.

We conducted the present study to clarify the prevalence of OBI in a series of curatively resected Japanese C-HCC patients, and we attempted to determine whether OBI affects the surgical outcomes of such patients.

\section{Methods}

\section{Patient backgrounds}

This study was approved by Saga University's medical ethics committee. Initially, 478 consecutive patients with primary hepatocellular carcinoma undergoing hepatic resection during the period from January 1984 to December 2012 were enrolled. Among them, 301 patients were serum HBsAg-negative and $\mathrm{HCV}$ antibody (Ab)-positive and thus considered C-HCC. Among these 301 patients, 276 underwent curative resection. Among these 276 patients, 19 were excluded because of lack of tissue or inappropriate tissue. Finally, 257 patients with $\mathrm{C}-\mathrm{HCC}$ were subjected to the study. All patients enrolled in this study had no lymph node metastasis or distant metastasis at the time of surgery.

Clinicopathological data such as age, gender, habitual alcohol drinking, diabetes, body mass index (BMI), ChildPugh classification, and indocyanine green retention rate at 15 minutes (ICG R15), serum albumin level, serum total bilirubin level, serum alpha-fetoprotein (AFP) level, serum protein induced by vitamin $\mathrm{K}$ absence or antagonists-II (PIVKA-II), tumor size, number of tumors, portal vein invasion $(\mathrm{Vp})$, and survival information were extracted from the patients' electronic medical records. ICGR15 data were unavailable for two patients, and serum PIVKA-II data were unavailable for 26 patients.

\section{Histopathological analysis}

The degree of fibrosis of noncancerous liver tissue was evaluated by two pathologists (K Kai and S Aishima). We used the New Inuyama classification, which is frequently used in Japan (F0, no fibrosis; F1, portal fibrosis widening; $\mathrm{F} 2$, portal fibrosis widening with bridging fibrosis; F3, bridging fibrosis plus lobular distortion; and F4, liver cirrhosis). 
Table 1 Status of occult HBV infection ( $\mathrm{n}=257)$

\begin{tabular}{ll}
\hline Status & Number (\%) \\
\hline Occult HBV infection & $15(5.8)$ \\
Positive & $242(94.2)$ \\
Negative & \\
Details of HBV amplification & $43(16.7)$ \\
HBc region & $21(8.2)$ \\
HBs region & $21(8.2)$ \\
HBx region & $71(27.6)$ \\
Amplification of at least one region &
\end{tabular}

\section{DNA extraction from liver tissue}

DNA was extracted from sections cut from formalin-fixed paraffin-embedded (FFPE) tissue blocks of noncancerous liver tissue $(<10 \mathrm{mg})$ using a NucleoSpin ${ }^{\circledR}$ DNA FFPE system (Takara Bio, Shiga, Japan) per the manufacturer's instructions. When we could not obtain enough noncancerous liver tissue, FFPE tissue of the tumor was alternatively subjected to the DNA extraction. The DNA was eluted in $30 \mu \mathrm{l}$ of Tris Borate EDTA buffer. The amount and quality of extracted DNA was confirmed by NanoDrop $^{\circledR}$ (Thermo Fisher Scientific, Yokohama, Japan).

\section{Detection of $\mathrm{HBV}-\mathrm{DNA}$ and the determination of $\mathrm{OBI}$}

The regions of HBs, hepatitis $\mathrm{B}$ core (HBc), and hepatitis $B \mathrm{x}(\mathrm{HBx})$ in the HBV DNA were analyzed by TaqMan real-time polymerase chain reaction (PCR) per the manufacturer's guidelines (TaqMan Fast Universal PCR Master Mix; Applied Biosystems, Foster City, CA). The oligonucleotide primers and probes which were specific for the $\mathrm{S}, \mathrm{X}$, and $\mathrm{C}$ regions of $\mathrm{HBV}$ were as described by Kondo et al. (19) Plasmid pBRHBadr72 (full-length HBV DNA) was used as an internal standard. Only the cases in which HBV DNA was detected by the TaqMan realtime PCR using at least two different sets of primers were considered to exhibit OBI.

\section{Statistical analysis}

The statistical analyses were performed using JMP ver. 13 software and SAS software ver. 9.4 (SAS Institute, Cary, NC). Student's $t$-test, $\chi^{2}$ test, and Fisher's exact test were used as appropriate for comparisons between two groups.
Disease-free survival (DFS) was determined as the length of time after surgery that the patient survived without new lesions of HCC. Overall survival (OS) was determined from the time of surgery to the time of death or the most recent follow-up. Disease-specific survival (DSS) was determined from the time of surgery to the time of cancer-related death or the most recent follow-up. The maximum followup period of our cohort is 10 years and median followup period including all death cases is 5.3 years. A Cox proportional hazards model was used for the univariate and multivariate analyses. The purpose of the multivariate analysis was to adjust potential covariates for the comparison of OBI status; then, age, gender, and OBI status were always kept in the model and others were selected by the stepwise procedure with the $\mathrm{P}$ value threshold of 0.2 . $\mathrm{P}$ values were two-sided, and those $<0.05$ were considered significant. All statistical analyzes were supervised by statisticians (S Komukai, A Kawaguchi).

\section{Results}

\section{OBI status}

The patients' OBI status is summarized in Table 1. Among the total of 257 cases, 15 (5.8\%) were defined as OBI. The details of HBV-DNA amplification by the TaqMan realtime PCR of each HBV-DNA region were as follows: 21 cases $(8.2 \%)$ in the $\mathrm{HBs}$ region, 21 cases $(8.2 \%)$ in the HBx region, and 43 cases $(16.7 \%)$ in the $\mathrm{HBc}$ region. Seventy-one $(27.6 \%)$ cases showed HBV-DNA amplification in at least one region.

\section{Comparison of clinicopathological features of the OBI and non-OBI groups}

The clinicopathological features of the $257 \mathrm{C}-\mathrm{HCC}$ patients are summarized in Table 2. The average patient's age was 67.5 years and there were 190 males $(73.9 \%)$ and 67 females (26.1\%). In the comparison of clinicopathological factors between the OBI group $(\mathrm{n}=15)$ and non-OBI group $(n=242)$, only diabetes mellitus showed a significant difference $(\mathrm{P}=0.0468)$; all of the diabetes mellitus cases were in the non-OBI group. No significant difference was observed between the OBI and non-OBI groups regarding age, gender, alcohol-drinking habit, BMI, Child-Pugh classification, ICG R15, liver fibrosis, serum albumin level, serum total bilirubin level, serum AFP level, serum PIVKA-II level, tumor size, number of tumors, Vp, T-stage, 
Table 2 Clinicopathologic features of the patients with C-HCC ( $\mathrm{n}=257)$ according to OBI status

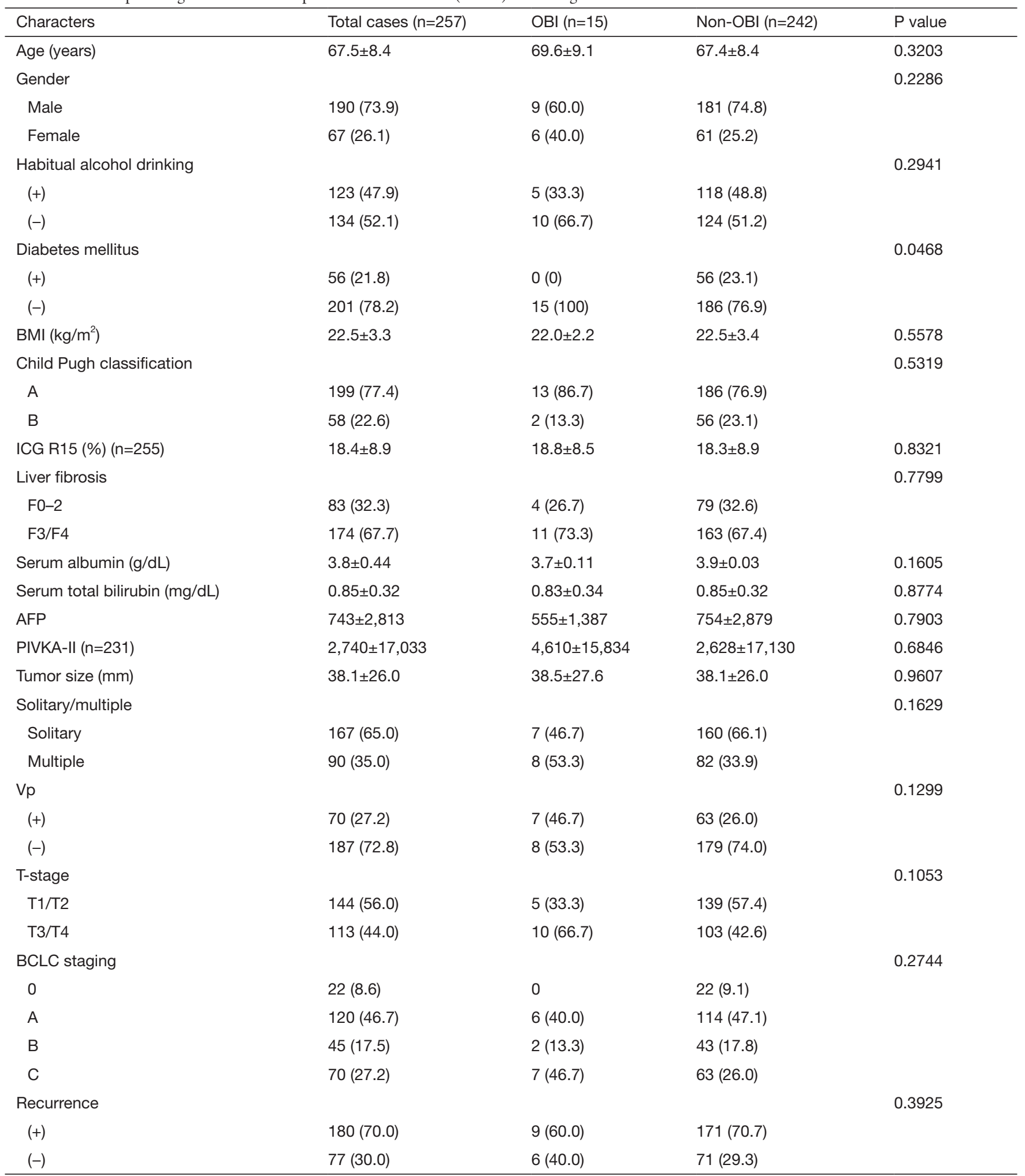

Data are shown as mean \pm SD or number (percentage). OBI, occult HBV infection; SD, standard deviation; BMI, body mass index; Vp, portal vein invasion; BCLC staging, Barcelona clinic liver cancer staging. 
Table 3 Univariate analyses for OS, DSS and DFS after hepatic resection

\begin{tabular}{|c|c|c|c|c|c|c|c|}
\hline Characteristics & $\mathrm{n}$ & \multicolumn{2}{|c|}{ OS } & \multicolumn{2}{|c|}{ DSS } & \multicolumn{2}{|c|}{ DFS } \\
\hline Age (years) & & & 0.5210 & & 0.4928 & & 0.4943 \\
\hline$>67$ & 135 & $1.11(0.81-1.52)$ & & $0.85(0.54-1.34)$ & & $1.11(0.83-1.48)$ & \\
\hline Gender & & & 0.6707 & & 0.3067 & & 0.2933 \\
\hline Male & 190 & $1.08(0.75-1.57)$ & & $1.34(0.76-2.36)$ & & $0.84(0.61-1.16)$ & \\
\hline Occult HBV infection & & & 0.3128 & & 0.0610 & & 0.8321 \\
\hline Absent & 242 & 1 & & 1 & & 1 & \\
\hline Present & 15 & 1.39 (0.73-2.64) & & $2.10(0.97-4.58)$ & & $0.93(0.48-1.82)$ & \\
\hline Diabetes mellitus & & & 0.8293 & & 0.8579 & & 0.5913 \\
\hline Absent & 201 & 1 & & 1 & & 1 & \\
\hline Present & 56 & $1.04(0.72-1.52)$ & & $1.05(0.61-1.80)$ & & $1.10(0.77-1.57)$ & \\
\hline BMI $\left(\mathrm{kg} / \mathrm{m}^{2}\right)$ & & & 0.0357 & & 0.3034 & & 0.1839 \\
\hline$\leq 25.0$ & 202 & 1 & & 1 & & 1 & \\
\hline$>25.0$ & 55 & $0.64(0.42-0.97)$ & & $0.74(0.41-1.32)$ & & $0.78(0.55-1.12)$ & \\
\hline Fibrosis & & & 0.1781 & & 0.2048 & & 0.0014 \\
\hline F0-2 & 83 & 1 & & 1 & & 1 & \\
\hline $\mathrm{T} 12$ & 144 & 1 & & 1 & & 1 & \\
\hline T34 & 113 & $1.74(1.27-2.38)$ & & $1.76(1.12-2.76)$ & & $1.79(1.34-2.41)$ & \\
\hline Solitary/multiple & & & 0.0002 & & 0.0893 & & 0.0021 \\
\hline Solitary & 167 & 1 & & 1 & & 1 & \\
\hline Multiple & 90 & 1.83 (1.33-2.52) & & $1.50(0.94-2.40)$ & & $1.62(1.19-2.20)$ & \\
\hline
\end{tabular}

OS, overall survival; DSS, disease-specific survival; DFS, disease-free survival; HR, hazard ratio; Cl, confidence interval; BMI, body mass index; Vp, portal vein invasion.

Barcelona clinic liver cancer (BCLC) staging and recurrence status.

\section{Univariate analyses for OS, DSS and DFS}

The results of the univariate analyses for OS, DSS and DFS are summarized in Table 3. The factors significantly correlated with OS were $\mathrm{BMI}>25 \mathrm{~kg} / \mathrm{m}^{2}[\mathrm{P}=0.0357$, hazard ratio $(\mathrm{HR})=0.64], \mathrm{Vp}(\mathrm{P}=0.0005, \mathrm{HR}=1.83)$, T-stage $(\mathrm{P}=0.0005, \mathrm{HR}=1.74)$, and multiple tumors $(\mathrm{P}=0.0002$, $\mathrm{HR}=1.83)$. The factors significantly correlated with DSS were $\mathrm{Vp}(\mathrm{P}=0.0423, \mathrm{HR}=1.67)$ and $\mathrm{T}$-stage $(\mathrm{P}=0.0141$, $\mathrm{HR}=1.76)$. The factors significantly correlated with DFS were liver fibrosis $(\mathrm{P}=0.0014, \mathrm{HR}=1.72)$, T-stage $(\mathrm{P}=0.0001$, 
Table 4 Multivariate analyses for OS, DSS, DFS

\begin{tabular}{|c|c|c|c|}
\hline Type & Characteristics & $\mathrm{HR}(95 \% \mathrm{Cl})$ & $P$ value \\
\hline \multirow[t]{7}{*}{ OS } & $\mathrm{OBI}$ & $0.98(0.50-1.92)$ & 0.9621 \\
\hline & Age (>67 years) & $1.02(0.74-1.40)$ & 0.9277 \\
\hline & Gender (male) & $1.10(0.75-1.60)$ & 0.6403 \\
\hline & $\mathrm{BMI}>25 \mathrm{~kg} / \mathrm{m}^{2}$ & $0.64(0.42-0.98)$ & 0.0416 \\
\hline & Liver fibrosis & $1.31(0.92-1.88)$ & 0.1397 \\
\hline & $\mathrm{Vp}$ & $1.64(1.15-2.35)$ & 0.0065 \\
\hline & Multiple tumor & 1.59 (1.14-2.22) & 0.0064 \\
\hline \multirow[t]{4}{*}{ DSS } & OBI & $2.15(0.97-4.77)$ & 0.0603 \\
\hline & Age (>67 years) & $0.87(0.55-1.38)$ & 0.5637 \\
\hline & Gender (male) & $1.36(0.76-2.42)$ & 0.2970 \\
\hline & T-stage & $1.67(1.06-2.63)$ & 0.0275 \\
\hline \multirow[t]{6}{*}{ DFS } & OBI & $0.67(0.33-1.35)$ & 0.2617 \\
\hline & Age (>67 years) & $1.16(0.86-1.56)$ & 0.3245 \\
\hline & Gender (male) & $0.86(0.61-1.21)$ & 0.3791 \\
\hline & $\mathrm{BMI}>25 \mathrm{~kg} / \mathrm{m}^{2}$ & $0.70(0.48-1.01)$ & 0.0532 \\
\hline & Liver fibrosis & $1.74(1.23-2.46)$ & 0.0017 \\
\hline & T-stage & $1.82(1.35-2.46)$ & 0.0001 \\
\hline
\end{tabular}

$\mathrm{HR}$, hazard ratio; $\mathrm{Cl}$, confidence interval; Vp, portal vein invasion; OS, overall survival; DSS, disease specific survival; DFS, disease free survival; OBI, occult HBV infection; BMI, body mass index.

$\mathrm{HR}=1.79)$, and multiple tumors $(\mathrm{P}=0.0021, \mathrm{HR}=1.62)$. No significance was observed for OBI status in the analysis of OS, DSS or DFS, although a tendency of poor outcome $(\mathrm{P}=0.0610, \mathrm{HR}=2.10)$ was observed for OBI status in the DSS analysis.

\section{Multivariate analyses for OS, DSS and DFS}

The results of multivariate analyses for OS, DSS and DFS are summarized in Table 4. The factors significantly correlated with OS were $\mathrm{BMI}>25 \mathrm{~kg} / \mathrm{m}^{2}(\mathrm{P}=0.0416$, $\mathrm{HR}=0.64), \mathrm{Vp}(\mathrm{P}=0.0065$, HR $=1.64)$, and multiple tumors $(\mathrm{P}=0.0064, \mathrm{HR}=1.59)$. The factor significantly correlated with DSS was only $\mathrm{T}$-stage $(\mathrm{P}=0.0275, \mathrm{HR}=1.67)$. The factors significantly correlated with DFS were liver fibrosis ( $\mathrm{P}=0.0017, \mathrm{HR}=1.74)$ and T-stage $(\mathrm{P}=0.0001, \mathrm{HR}=1.82)$. No significance was observed for OBI in each multivariate analysis of OS, DSS and DFS, although a tendency of poor outcome ( $\mathrm{P}=0.0603, \mathrm{HR}=2.15)$ was observed for OBI status in the DSS analysis.

\section{Discussion}

Although many studies have described the co-infection of HCV and OBI, the prevalence of OBI varies widely from region to region worldwide (5-8,10-18,21-25). The prevalence and HBV-DNA detection method used to examine previous series of $\mathrm{HCV}$-infection cases are summarized in Table 5. The previously reported prevalence of OBI in cases with HCV infection varies from $5.2 \%$ to $76 \%(5-8,10-18,21-25)$. The prevalence of OBI in the present investigation of 257 patients with $\mathrm{HCV}$ infection was $5.8 \%$. This result seems relatively low compared to the previous studies. However, all of the prior Japanese studies analyzing OBI in HCV-infected patients reported low OBI prevalence values, ranging from $5.2 \%$ to $7.8 \%(7,10,18)$, and our present result is thus reasonable for a Japanese population. As demonstrated in Table 5, our study is the largest analysis regarding $\mathrm{OBI}$ and $\mathrm{C}-\mathrm{HCC}$ in a Japanese population.

Previous studies conducted in Japan and our present findings suggest that the prevalence of co-infection of $\mathrm{HCV}$ and OBI is lower in Japan than other countries. However, the differences in the prevalence of OBI may be due in part to the lack of methodological uniformity among the different studies (26). The previous Japanese series and the present study used real-time PCR using TaqMan probes, which have high specificity $(7,10,18)$, whereas many previous studies from other countries regarding OBI and C-HCC (Table 5) were based on single-step or nested PCR $(6,11-13,22)$, and the definition of OBI is not uniform among the studies.

The 2008 Taormina expert meeting (26) defined OBI as "the presence of HBV-DNA in the liver (with detectable or undetectable HBV DNA in the serum) of individuals testing HBsAg-negative by currently available assays" and recommended the analysis of DNA extracts from liver as well as from blood samples by real-time PCR or nested PCR using oligonucleotide primers specific for different HBV genomic regions. In the present study, OBI was determined by the HBV-DNA amplification of at least two different sets of primers by TaqMan real-time PCR.

The distinctive feature of present study is the use of DNA extracts from FFPE samples. As all previous OBI studies were based on frozen/raw liver tissue or serum 


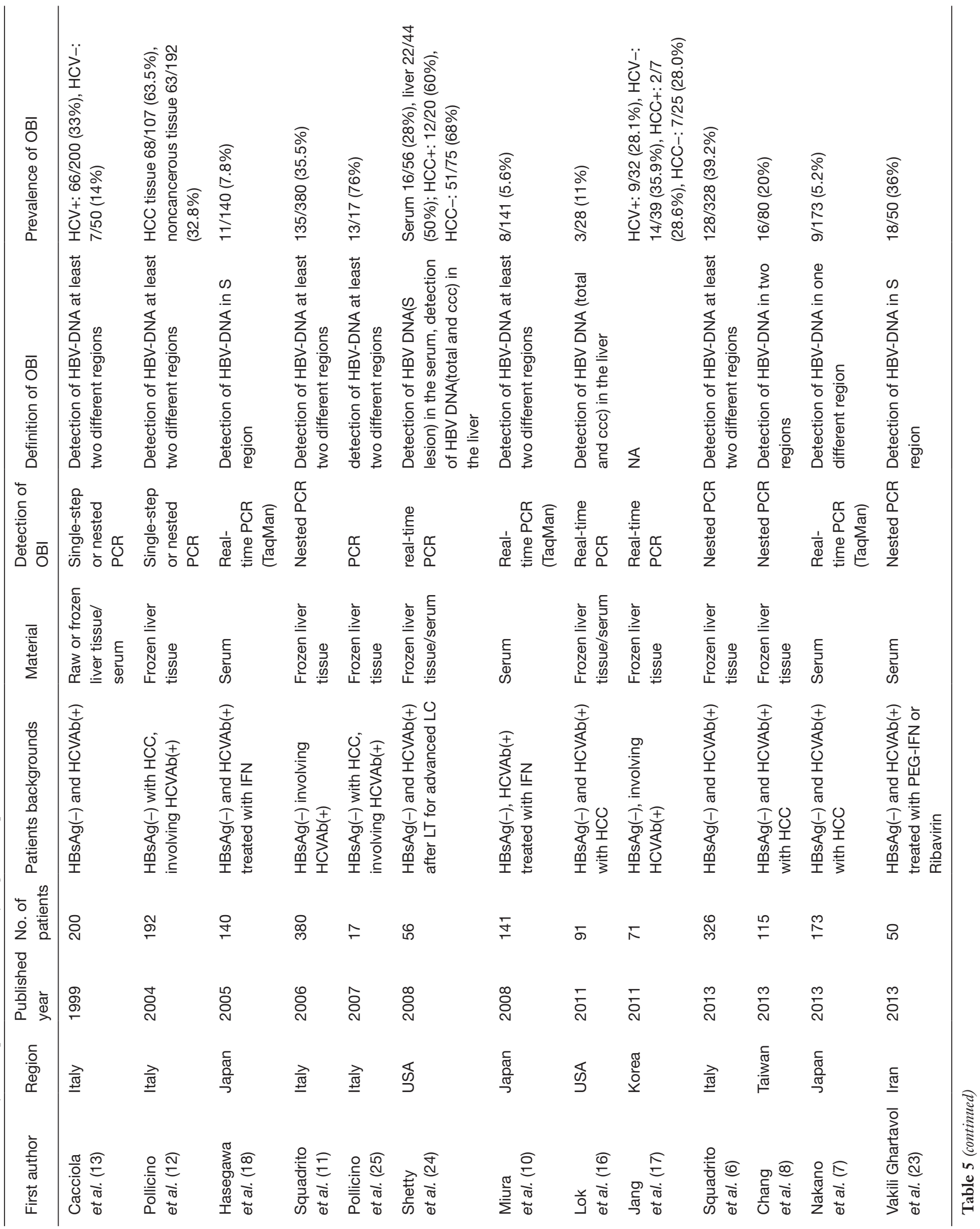




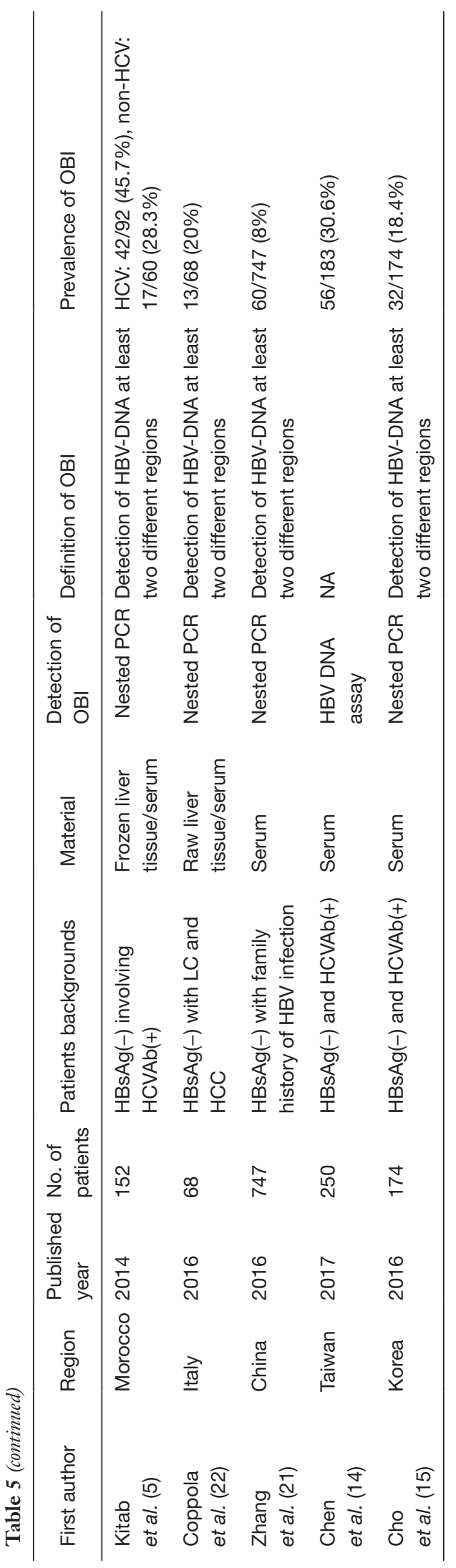

samples $(5-8,10-18,21-26)$, it was challenging to analyze the OBI status from FFPE samples. We therefore performed a pilot study using DNA extracted from FFPE tissues of overt HBV infection cases, and the results confirmed good $\mathrm{HBV}$ amplification in each primer set, even in old samples. We previously performed an analysis of OBI using FFPE liver tissue in 78 cases of NBNC-HCC and obtained the reasonable result of $34.6 \%$ OBI prevalence (20). Of course, although the ideal material for OBI testing is frozen/raw liver tissue, our studies suggest the usefulness of FFPE tissue for OBI testing.

Many previous studies evaluating the role of anti-HBcAb in the development of cirrhosis in HBsAg-negative patients with $\mathrm{CHC}$ (27) reported a significant association between anti-HBcAb and liver cirrhosis (28-35), but a few studies did not find such an association (36-38). Most of the previous OBI studies evaluating the role of HBV-DNA in serum and/ or liver tissue in the development of cirrhosis in HBsAgnegative patients with $\mathrm{CHC}$ reported a negative association between OBI and cirrhosis (33,36,39-44), although other reports describe a significant association $(6,13,45-47)$. In the present study, OBI status was not associated with the degree of liver fibrosis.

One of the main purposes of the present study was to verify whether OBI affects surgical outcomes of C-HCC patients. This issue has not been a focus of clinical research. We could find only one study from Taiwan analyzing surgical outcomes of 115 cases of C-HCC. Their results indicated that the OBI $(n=16)$ or overt HBV $(n=35)$ coinfection of HCV served as an independent predictor for postoperative survival in C-HCC (8). In contrast, our present findings indicate a negative association between OBI and surgical outcomes of curatively resected C-HCC patients. However, a weak association between OBI and poor outcome was observed in both the univariate $(\mathrm{P}=0.0610, \mathrm{HR}=2.10)$ and multivariate $(\mathrm{P}=0.0603$, $\mathrm{HR}=2.15$ ) analyses of DSS, although it was not significant. It is thus possible that if a greater number of cases were analyzed, a significant correlation of OBI and poor outcome may be observed. Taken together, our results suggest that to make any conclusion regarding the influence of OBI on surgical outcomes of C-HCC, a further accumulation of the studies is needed.

In the multivariate analyses, the factors significantly correlated with surgical outcomes were mostly tumorrelated factors, i.e., $\mathrm{Vp}$, T-stage and multiple tumors. The natural history of C-HCC is that C-HCC often multicentrically develops in cirrhotic liver (48), and it 
seems reasonable that the degree of fibrosis of background liver was significantly correlated with DFS in the present study. We also observed that obesity (BMI $>25 \mathrm{~kg} / \mathrm{m}^{2}$ ) is an independent favorable prognostic factor in OS. This result is consistent with a previous report that indicated obesity positively affected the surgical outcomes of patients with HCV-related HCC (49).

The limitations of our study were its retrospective nature, the long study period, the small number of patients (especially OBI patients), and the study's single-institution design. Information about neoadjuvant treatments, postoperative therapies, therapy for $\mathrm{HCV}$ infection, virological $\mathrm{HCV}$ status, serum $\mathrm{HBc}-\mathrm{Ab}, \mathrm{HBs}-\mathrm{Ab}$ and serum HBV-DNA status was not available. Diagnostic and therapeutic modalities have also changed in recent years. Large retrospective or prospective studies adjusting preand post-operative therapeutic conditions would be ideal to determine the precise relationship between OBI and surgical outcomes of HCV-related HCC patients.

In conclusion, we analyzed the OBI status in 257 cases of C-HCC by using FFPE liver tissues. We identified OBI in 15 cases $(5.8 \%)$. We found no significant correlation between OBI and surgical outcomes, although a weak association between DFS and OBI was observed and statistical analyses were limited by small number of OBI cases. We expect that further studies will clarify the relationship between OBI and C-HCC.

\section{Acknowledgements}

Funding: This study was supported in part by Japan Society for the Promotion of Science (JSPS) KAKENHI (Grants-in-Aid for Scientific Research C) Grant Number JP16K08650.

\section{Footnote}

Conflicts of Interest: The authors declare that there is no conflict of interest regarding the publication of this article.

Ethical Statement: This study was approved by Saga University's medical ethics committee (approval no. 27-18). Written informed consent was obtained from all patients.

\section{References}

1. Hori M, Matsuda T, Shibata A, et al. Cancer incidence and incidence rates in Japan in 2009: A study of 32 population- based cancer registries for the Monitoring of Cancer Incidence in Japan (MCIJ) project. Jpn J Clin Oncol 2015;45:884-91.

2. Umemura T, Ichijo T, Yoshizawa K, et al. Epidemiology of hepatocellular carcinoma in Japan. J Gastroenterol 2009;44:102-7.

3. Makvandi M. Update on occult hepatitis B virus infection. World J Gastroenterol 2016;22:8720-34.

4. Pollicino T, Saitta C. Occult hepatitis B virus and hepatocellular carcinoma. World J Gastroenterol 2014;20:5951-61.

5. Kitab B, Ezzikouri S, Alaoui R, et al. Occult HBV infection in Morocco:From chronic hepatitis to hepatocellular carcinoma. Liver Int 2014;34:e144-50.

6. Squadrito G, Cacciola I, Alibrandi A, et al. Impact of occult hepatitis B virus infection on the outcome of chronic hepatitis C. J Hepatol 2013;59:696-700.

7. Nakano M, Kawaguchi T, Nakamoto S, et al. Effect of occult hepatitis $B$ virus infection on the early-onset of hepatocellular carcinoma in patients with hepatitis $\mathrm{C}$ virus infection. Oncol Rep 2013;30:2049-55.

8. Chang ML, Lin YJ, Chang CJ, et al. Occult and overt $\mathrm{HBV}$ co-infections independently predict postoperative prognosis in $\mathrm{HCV}$-associated hepatocellular carcinoma. PLoS One 2013;8:e64891.

9. Shi $\mathrm{Y}, \mathrm{Wu} \mathrm{YH}, \mathrm{Wu} W$, et al. Association between occult hepatitis B infection and the risk of hepatocellular carcinoma: A meta-analysis. Liver Int 2012;32:231-40.

10. Miura Y, Shibuya A, Adachi S, et al. Occult hepatitis B virus infection as a risk factor for hepatocellular carcinoma in patients with chronic hepatitis $\mathrm{C}$ in whom viral eradication fails. Hepatol Res 2008;38:546-56.

11. Squadrito G, Pollicino T, Cacciola I, et al. Occult hepatitis $\mathrm{B}$ virus infection is associated with the development of hepatocellular carcinoma in chronic hepatitis $\mathrm{C}$ patients. Cancer 2006;106:1326-30.

12. Pollicino T, Squadrito G, Cerenzia G, et al. Hepatitis B virus maintains its pro-oncogenic properties in the case of occult HBV infection. Gastroenterology 2004;126:102-10.

13. Cacciola I, Pollicino T, Squadrito G, et al. Occult hepatitis $\mathrm{B}$ virus infection in patients with chronic hepatitis $\mathrm{C}$ liver disease. N Engl J Med 1999;341:22-6.

14. Chen HY, Su TH, Tseng TC, et al. Impact of occult hepatitis $\mathrm{B}$ on the clinical outcomes of patients with chronic hepatitis $\mathrm{C}$ virus infection: A 10-year follow-up. J Formos Med Assoc 2017;116:697-704.

15. Cho J, Lee SS, Choi YS, et al. Occult hepatitis B virus infection is not associated with disease progression of 
chronic hepatitis C virus infection. World J Gastroenterol 2016;22:9427-36.

16. Lok AS, Everhart JE, Di Bisceglie AM, et al. Occult and previous hepatitis B virus infection are not associated with hepatocellular carcinoma in United States patients with chronic hepatitis C. Hepatology 2011;54:434-42.

17. Jang JY, Jeong SW, Cheon SR, et al. Clinical significance of occult hepatitis $\mathrm{B}$ virus infection in chronic hepatitis $\mathrm{C}$ patients. Korean J Hepatol 2011;17:206-12.

18. Hasegawa I, Orito E, Tanaka Y, et al. Impact of occult hepatitis B virus infection on efficacy and prognosis of interferon-alpha therapy for patients with chronic hepatitis C. Liver Int 2005;25:247-53.

19. Kondo R, Nakashima O, Sata M, et al. Pathological characteristics of patients who develop hepatocellular carcinoma with negative results of both serous hepatitis $\mathrm{B}$ surface antigen and hepatitis $\mathrm{C}$ virus antibody. Hepatol Res 2014;44:1039-46.

20. Koga H, Kai K, Aishima S, et al. Occult hepatitis B virus infection and surgical outcomes in non-B, non-C patients with curative resection for hepatocellular carcinoma. World J Hepatol 2017;9:1286-95.

21. Zhang Z, Zhang L, Dai Y, et al. Occult hepatitis B virus infection: Influence of $\mathrm{S}$ protein variants. Virol J 2016;13:10.

22. Coppola N, Onorato L, Iodice V, et al. Occult HBV infection in HCC and cirrhotic tissue of HBsAg-negative patients:A virological and clinical study. Oncotarget 2016;7:62706-14.

23. Vakili Ghartavol Z, Alavian SM, Amini S, et al. Prevalence of occult hepatitis $B$ virus in plasma and peripheral blood mononuclear cell compartments of patients with chronic hepatitis C infection in Tehran, Iran. Hepat Mon 2013;13:e10134.

24. Shetty K, Hussain M, Nei L, et al. Prevalence and significance of occult hepatitis B in a liver transplant population with chronic hepatitis C. Liver Transpl 2008;14:534-40.

25. Pollicino T, Raffa G, Costantino L, et al. Molecular and functional analysis of occult hepatitis $\mathrm{B}$ virus isolates from patients with hepatocellular carcinoma. Hepatology 2007;45:277-85.

26. Raimondo G, Allain JP, Brunetto MR, et al. Statements from the Taormina expert meeting on occult hepatitis $B$ virus infection. J Hepatol 2008;49:652-7.

27. Coppola N, Onorato L, Pisaturo M, et al. Role of occult hepatitis B virus infection in chronic hepatitis C. World J Gastroenterol 2015;21:11931-40.
28. Carvalho-Filho RJ, de Lucca Schiavon L, NarcisoSchiavon JL, et al. Clinical and histological impact of previous hepatitis $B$ virus infection in patients with chronic hepatitis C. Liver Int 2009;29:133-40.

29. Coppola N, Gentile I, Pasquale G, et al. Anti-HBc positivity was associated with histological cirrhosis in patients with chronic hepatitis C. Ann Hepatol 2013;13:20-6.

30. De Maria N, Colantoni A, Friedlander L, et al. The impact of previous HBV infection on the course of chronic hepatitis C. Am J Gastroenterol 2000;95:3529-36.

31. Dinis-Ribeiro M, Ramalho F, Gloria H, et al. Factors associated with the development of cirrhosis in patients with $\mathrm{HCV}$ chronic infection. Hepatogastroenterology 2005;52:176-9.

32. El-Sherif A, Abou-Shady M, Abou-Zeid H, et al. Antibody to hepatitis $\mathrm{B}$ core antigen as a screening test for occult hepatitis $\mathrm{B}$ virus infection in Egyptian chronic hepatitis $\mathrm{C}$ patients. J Gastroenterol 2009;44:359-64.

33. Giannini E, Ceppa P, Botta F, et al. Previous hepatitis B virus infection is associated with worse disease stage and occult hepatitis $B$ virus infection has low prevalence and pathogenicity in hepatitis $C$ virus-positive patients. Liver Int 2003;23:12-8.

34. Helmy A, Al-Sebayel MI. Isolated antibody to hepatitis $\mathrm{B}$ core antigen in patients with chronic hepatitis $\mathrm{C}$ virus infection. World J Gastroenterol 2006;12:4406-10.

35. Sagnelli E, Coppola N, Scolastico C, et al. Virologic and clinical expressions of reciprocal inhibitory effect of hepatitis $\mathrm{B}, \mathrm{C}$, and delta viruses in patients with chronic hepatitis. Hepatology 2000;32:1106-10.

36. Laguno M, Larrousse M, Blanco JL, et al. Prevalence and clinical relevance of occult hepatitis $\mathrm{B}$ in the fibrosis progression and antiviral response to INF therapy in HIVHCV-coinfected patients. AIDS Res Hum Retroviruses 2008;24:547-53.

37. Levast M, Larrat S, Thelu MA, et al. Prevalence and impact of occult hepatitis B infection in chronic hepatitis $\mathrm{C}$ patients treated with pegylated interferon and ribavirin. J Med Virol 2010;82:747-54.

38. Verbaan H, Widell A, Bondeson L, et al. Factors associated with cirrhosis development in chronic hepatitis $\mathrm{C}$ patients from an area of low prevalence. J Viral Hepat 1998;5:43-51.

39. Fukuda R, Ishimura N, Niigaki M, et al. Serologically silent hepatitis $\mathrm{B}$ virus coinfection in patients with hepatitis $\mathrm{C}$ virus-associated chronic liver disease:Clinical and virological significance. J Med Virol 1999;58:201-7.

40. Hui CK, Lau E, Monto A, et al. Natural history of 
patients with recurrent chronic hepatitis $C$ virus and occult hepatitis B co-infection after liver transplantation. Am J Transplant 2006;6:1600-8.

41. Hui CK, Lau E, Wu H, et al. Fibrosis progression in chronic hepatitis $\mathrm{C}$ patients with occult hepatitis $\mathrm{B}$ coinfection. J Clin Virol 2006;35:185-92.

42. Sagnelli E, Imparato M, Coppola N, et al. Diagnosis and clinical impact of occult hepatitis B infection in patients with biopsy proven chronic hepatitis $\mathrm{C}$ : A multicenter study. J Med Virol 2008;80:1547-53.

43. Silva C, Goncales NS, Pereira JS, et al. The influence of occult infection with hepatitis B virus on liver histology and response to interferon treatment in chronic hepatitis C patients. Braz J Infect Dis 2004;8:431-9.

44. Torbenson M, Kannangai R, Astemborski J, et al. High prevalence of occult hepatitis B in Baltimore injection drug users. Hepatology 2004;39:51-7.

45. Emara MH, El-Gammal NE, Mohamed LA, et al. Occult

Cite this article as: Yamaji K, Kai K, Komukai S, Koga H, Ide T, Kawaguchi A, Noshiro H, Aishima S. Occult HBV infection status and its impact on surgical outcomes in patients with curative resection for $\mathrm{HCV}$-associated hepatocellular carcinoma. HepatoBiliary Surg Nutr 2018;7(6):443-453. doi: 10.21037/hbsn.2018.10.01 hepatitis B infection in egyptian chronic hepatitis C patients: Prevalence, impact on pegylated interferon/ ribavirin therapy. Virol J 2010;7:324.

46. Matsuoka S, Nirei K, Tamura A, et al. Influence of occult hepatitis $\mathrm{B}$ virus coinfection on the incidence of fibrosis and hepatocellular carcinoma in chronic hepatitis C. Intervirology 2008;51:352-61.

47. Mrani S, Chemin I, Menouar K, et al. Occult HBV infection may represent a major risk factor of nonresponse to antiviral therapy of chronic hepatitis C. J Med Virol 2007;79:1075-81.

48. But DY, Lai CL, Yuen MF. Natural history of hepatitisrelated hepatocellular carcinoma. World J Gastroenterol 2008;14:1652-6.

49. Hashimoto M, Tashiro H, Kobayashi T, et al. Influence of higher BMI for hepatitis B- and C-related hepatocellular carcinomas. Langenbecks Arch Surg 2017;402:745-55. 